\title{
Effect of Professional Development on Classroom Practices in Some Selected Saudi Universities
}

\author{
AbdulKhaliq Hajjad Alghamdi ${ }^{1} \&$ Ahmad Johari Bin Sihes ${ }^{1}$ \\ ${ }^{1}$ Faculty of Education, UTM, Malaysia \\ Correspondence: AbdulKhaliq Hajjad Alghamdi, Faculty of Education, UTM, Malaysia. Tel: 966-55-808-3131. \\ Received: November 21, 2015 \\ Accepted: December 11, 2015 \\ Online Published: December 16, 2015 \\ doi:10.5430/ijhe.v5n1p152 \\ URL: http://dx.doi.org/10.5430/ijhe.v5n1p152
}

\begin{abstract}
Scientific studies found the impact of professional development on effective classroom practices in Higher Education. This paper hypothesizes no statistically significant effect of lecturers' professional development on classroom practices in some selected Saudi Universities not as highlighted in the model. Hierarchical multiple regression was used to showcase the effects of professional development factors on classroom practices. The sample of this study consisted of 45 professionally trained lecturers randomly selected from the three Saudi Universities. The study found that teaching competence has a positive statistically significant relationship with the classroom practices, next is technology, evaluation competence, human competence, and cultural competence are among the variables found to have weak effects on classroom practices in Saudi Universities.
\end{abstract}

Keywords: Professional development, Classroom practices, Saudi universities

\section{Introduction}

\subsection{Introduction}

Educators and educational stakeholders across the globe are exploring ways to making changes in higher learning institutions through developing the teaching staff professionally. Professional development is defined as the holistic and sustained approach to improving teachers' effectiveness in making students' higher achievers (National Staff Development Council, 2009). Guskey (1985) stressed that educational professional development encompasses structured activities in enhancing educators' professional skills, keeping them to-date or supporting changes in educational environment. The main perceived professional development factors demonstrated in the literature that contribute to the perceived quality of effective classroom change are human competence (Schnonert-Reichl \& Lawlor, (2010), technology competence (Hansen, Hennig-Thurau, \& Wochnowski, 2000) teaching competence, cultural and evaluative competence (Wong \& Moni, 2014). Existing literature found that, teaching methodology, teacher ability to respond to students' queries, control students' unwanted behavior, and reflection (Ratcliff, Jones, Costner, Savage-Davis \& Hunt, 2010) are best factors that reflect the classroom practices.

Fortunately, many organizations support and encourage their staff development to become well-rounded in their field (Lebeau, 2008) and many others do not. In the light of the abovementioned assertions, this study investigated the causal relationship between lecturers' professional development and classroom practices in Saudi Arabia in accordance with the theory of (Guskey, 1985) and the existing related literature.

\subsection{Statement of Problem}

Guskey's, $(1985 ; 2002)$ theory was used to investigate the effect of professional development on classroom practices in some selected Saudi Universities. Studies that examine this effect are few (Berman \& Ritchie, 2006) in Arab countries and specifically in Saudi Arabia. Empirical studies affirmed that most of the Saudi teachers lack the use of modern technologies in the lecture rooms (An-Nuh, 2006; As-Shahrani, 2013). Additionally, there is a lack of scientific study according to the literature examining the effect of staff professional development on classroom practices in Saudi Arabia. In order to fill and reduce the gap in literature, the following research hypothesis was formulated.

\subsection{Research Hypothesis}

Professional development has no statistically significant relationship with classroom practices in Saudi Arabia. 


\subsection{Guskey's Model}

Guskey's (1985) model centered on the recent trends in educational professional development which encompasses structured activities or courses in the workplace to enhance professional skills of educators and keep them up-to date or support changes in any organizational setting. Guskey $(1985 ; 2002)$ proposed that professional development is a systematic attempt that brings about change. Guskey (1985) specifically described the change components as: (a) change in the classroom practices of teachers, (b) change in teacher's beliefs and attitudes, and (c) change in the learning outcomes of students.

Guskey $(1985 ; 2002)$ believed that teachers need to change their educational narrative namely; beliefs and attitudes first, before they can change instructional practices. In his view, real changes in teacher's narrative will bring changes to student's outcomes. His model for teacher-change is based on the idea that change is a developmental learning process for teachers and primarily experientially-based. Fig 1 depicts the Guskey (1985) model.

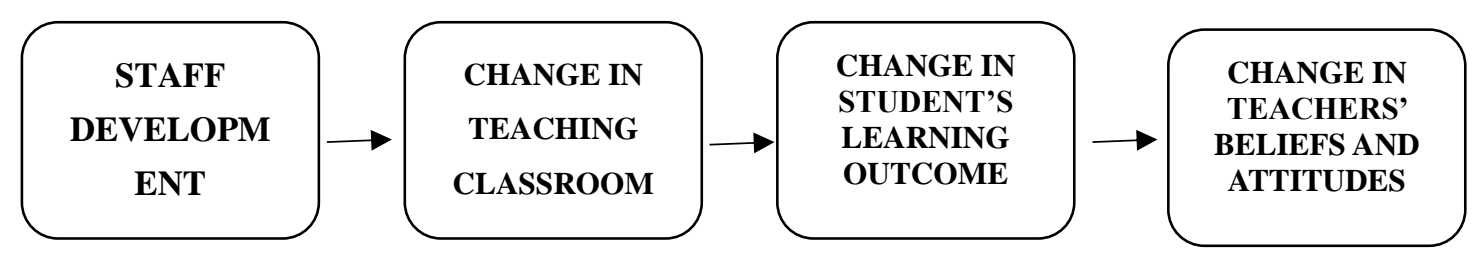

\section{Method}

Figure 1. Staff Development and Teacher Change

This study was a pure quantitative. The samples of the study consisted of 45 faculty members from three Saudi Universities namely; Umm Al-Qura University, King Saud University, and Al-Baha University who were drawn purposively. 15 faculty members represented each University. After gathering the information about the respondents from the postgraduate offices of each respondent's university. An official letter was sent to the respondents seeking their participation in the study before the administration of the research instrument. The instrument of the study was survey questionnaire. The instrument contained 39 items using six rating scale ranging from (1) strongly disagree (2) disagree (3) slightly disagree (4) slightly agree (5) agree and (6) strongly agree. The instrument used was adopted from Al-Sharif, Morena-Murica, Torregrosa and Pedreno (2015) and slightly modified to suit the purpose of this study. The reliability of the instrument was run using Cronbach alpha as shown in Table 1 through 6 . The validity of the instrument was tested using back translation and face validity. The instrument face validity was carried out by three experts in the field of education.

Table 1. Items for measuring teaching competence

\begin{tabular}{llll}
\hline Items & SD & D SLD SLA A SA \\
\hline I need to attend Continuous Professional Development program to improve my & & & \\
teaching competence generally & & & \\
I need to attend CPD program in preparing my lecture before its time. & & & \\
I need to attend CPD program to help me manage the time efficiently. & & & \\
I need to attend CPD program to make my class students' centered. & & & \\
I need to attend CPD program in diverse teaching methods. & & & \\
I need to attend CPD in controlling students' behaviors. & & \\
Cronbach Alpha $\mathbf{8 8}$ & & &
\end{tabular}

Table 1 explains the six items used for measuring teaching competence on a five-Likert rating scale. The reliability of the items is .88 . 
Table 2. Items for measuring human competence

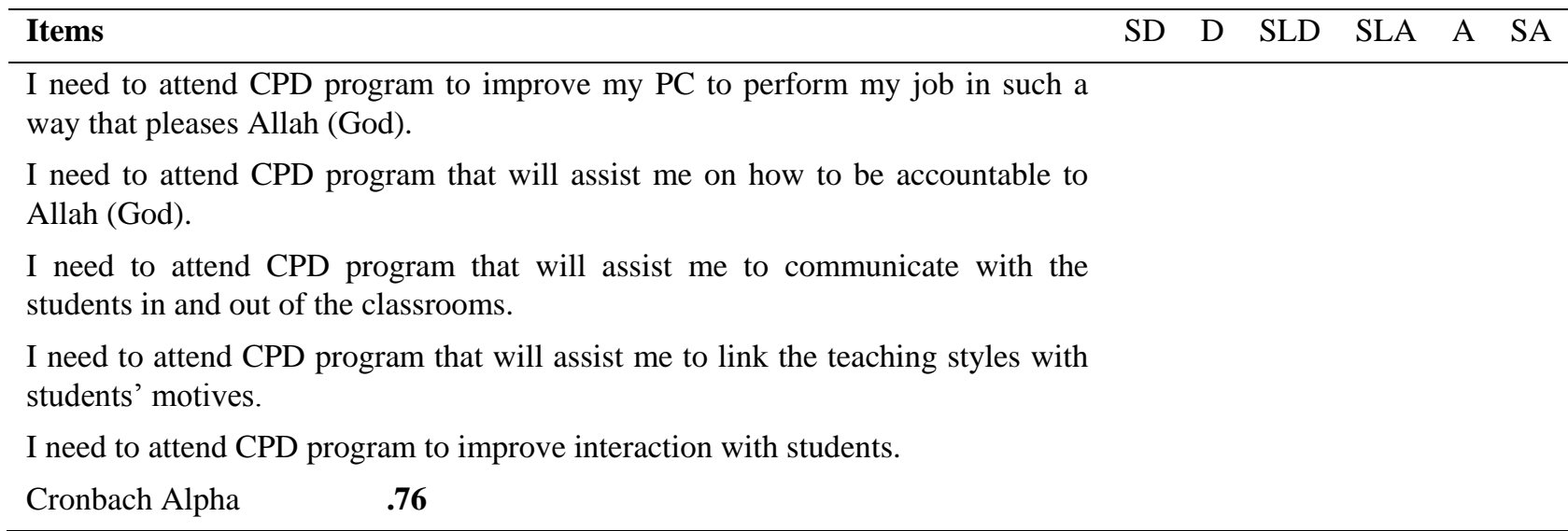

Table 2 explains that five items were used for measuring human competence on a five-Likert rating scale. The reliability of the items is .76.

Table 3. Items for measuring technology competence

\begin{tabular}{|c|c|c|c|c|c|}
\hline Items & SD & SLD & SLA & A & SA \\
\hline \multicolumn{6}{|l|}{$\begin{array}{l}\text { I need to attend CPD program to improve the use of social network device via } \\
\text { smart phone in teaching and learning. }\end{array}$} \\
\hline \multicolumn{6}{|l|}{$\begin{array}{l}\text { I need to attend CPD program on how to use social network device in making } \\
\text { teaching attractable to students. }\end{array}$} \\
\hline \multicolumn{6}{|l|}{$\begin{array}{l}\text { I need to attend CPD program to know the benefits of using social network } \\
\text { device in teaching and learning. }\end{array}$} \\
\hline \multicolumn{6}{|l|}{$\begin{array}{l}\text { I need to attend CPD program to improve my abilities to use the computer in } \\
\text { preparing and presenting lectures. }\end{array}$} \\
\hline \multicolumn{6}{|l|}{$\begin{array}{l}\text { I need to attend CPD program to improve my abilities to use the smart board in } \\
\text { presenting lectures. }\end{array}$} \\
\hline \multicolumn{6}{|l|}{$\begin{array}{l}\text { I need to attend CPD program to improve my abilities to use project in presenting } \\
\text { lectures. }\end{array}$} \\
\hline Cronbach Alpha .74 & & & & & \\
\hline
\end{tabular}

Table 3 explains that six items were used for measuring technology competence on a five-Likert rating scale. The reliability of the items is .74 .

Table 4. Items for measuring evaluation competence

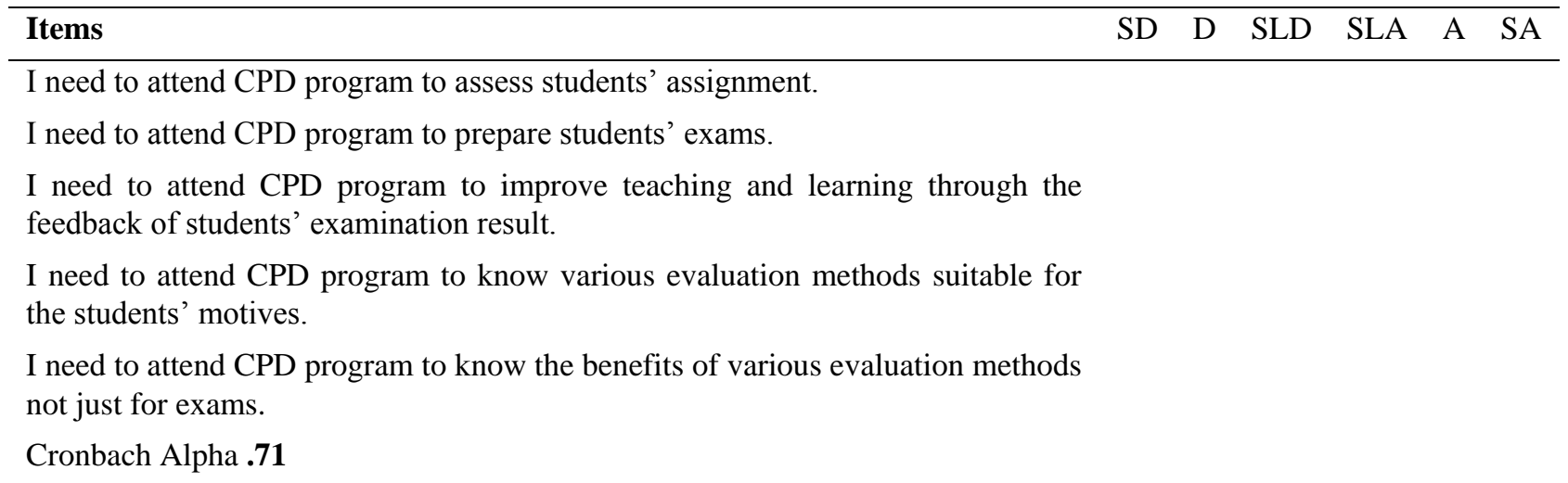

Table 4 explains that five items were used for measuring evaluative competence on a five-Likert rating scale. The reliability of the items is .71 . 
Table 5. Items for measuring cultural competence

\begin{tabular}{|c|c|c|c|c|c|}
\hline Items & SD $\quad \mathrm{D}$ & SLD & SLA & A & SA \\
\hline $\begin{array}{l}\text { I need to attend CPD program to change the staff academic culture in improving } \\
\text { teaching and learning. }\end{array}$ & & & & & \\
\hline I need to attend CPD program to change students' culture towards learning. & & & & & \\
\hline $\begin{array}{l}\text { I need to attend CPD program to change the culture of the University community } \\
\text { in improving teaching and learning. }\end{array}$ & & & & & \\
\hline $\begin{array}{l}\text { I need to attend CPD program to change the culture of the external community in } \\
\text { improving teaching and learning. }\end{array}$ & & & & & \\
\hline $\begin{array}{l}\text { I need to attend CPD program to effectively utilize the culture of teaching and } \\
\text { learning. }\end{array}$ & & & & & \\
\hline Cronbach Alpha .70 & & & & & \\
\hline
\end{tabular}

Table 5 explains that five items were used for measuring cultural competence on a five-Likert rating scale. The reliability of the items is .70.

Table 6. Items for measuring classroom practices are:

\begin{tabular}{l}
\hline Items \\
I make the classroom effective because I use brainstorming method. \\
I make the classroom active because I use problem solving method. \\
I can use different methods of teaching to deliver lectures in the classroom \\
because I know they will work very well. \\
I usually answer students' question positively. \\
I help students to find answer to their questions. \\
I am not able to answer students' questions during the lecture time. \\
I know the way to put an end to students' late coming to the class. \\
I can control students who make noises in the classroom. \\
I cannot control students' unwanted behavior in the classroom. \\
I give a chance to students to reflect on what I present to them. \\
I specify the time in the lecture to reflect with students on the main topic. \\
I do not give a chance to students to reflect either before or after the lecture. \\
Cronbach Alpha .79 \\
\end{tabular}

Table 6 explains that twelve items were used for measuring classroom practices on five-Likert scale. The reliability of the items is .79.

Back translation was utilized to translate the instrument from Arabic to English for more clarity before the data collection and from Arabic back to English after the data collection. The translation of the research instrument underwent two phases. The first phase involves giving the Arabic version of the research instrument to two experts who are proficient in Arabic and English for translation. The second phase is the referral of the first and second English translations of the instrument to another translator for review in checking for the original translation of the instrument to avoid error. The This study hypothesizes that, developing Saudi teachers in terms of teaching competence, human competence, technology competence, evaluation competence, cultural competence, and teaching methodology might not necessarily bring forth a perceived change in the learning classroom in Saudi context. The crucial point is that it is not the professional development per se, but the experience of successful implementation that changes teachers' attitudes and beliefs about the classroom practices. To either reject or fail to reject the research null hypothesis, the hierarchical multiple regression was run to investigate the results.

\section{Results and Discussions}

The results of the demographic information of the respondents who participated in the study across the three selected Universities in Saudi Arabia are shown in Table 7. 
Table 7. Demographic data of the respondents

Demographic

University

Umm AlQura

King Saud

AlBaha

\section{Qualification}

Bachelor

Master's Degree

$\mathrm{PhD}$

Position

Assistant Lecturer

Lecturer

Assistant Prof.

Associate Prof.

Prof.

Teaching Experience

1-5

6-10

11-15

16-20

21-25

26 and above

\section{Specialization}

Sciences

Arts

N \%

$15 \quad 33$

$15 \quad 33$

$15 \quad 33$

$6 \quad 13$

$12 \quad 27$

$27 \quad 60$

$6 \quad 13$

$12 \quad 27$

$13 \quad 29$

$11 \quad 24$

$3 \quad 7$

$6 \quad 13$

$4 \quad 9$

$9 \quad 20$

$3 \quad 7$

$10 \quad 22$

$13 \quad 29$

$26 \quad 58$

$19 \quad 42$

PD Seminars and Workshops Attended

No Course

$14 \quad 31$

1-3 Courses

$8 \quad 18$

$7 \quad 16$

4-6 Courses

$11 \quad 24$

7-9 Courses

$5 \quad 11$

10 and above

\section{PD Time}

Never

$13 \quad 29$

$1-5$ hours

12

6-10 hours

920

11-less than a week

$12 \quad 27$

More than a week

$10 \quad 22$

Table 7 shows that the respondents who participated in the study were equally from the three outstanding universities in Saudi Arabia. Majority of them were PhD holders $(n=27)$, assistant professors $(n=13)$, have more than 26 years 
of teaching experiences, were in the science mainstream, have not attended any seminars and workshops related to professional development programs, and have never taken time to attend any professional development program.

In order to investigate the effect of professional development program on classroom practices according to the theory employed to either reject or fail to reject the null hypothesis. Table 8 presents the results of the hierarchical multiple regression.

Table 8. Model Summary and Coefficients

\section{Standardized Coefficients}

\begin{tabular}{|c|c|c|c|c|c|c|c|c|}
\hline Model & $\mathrm{R}$ & $\mathrm{R}^{2}$ & Std. Err & Beta & $\mathrm{t}$ & df & Sig. & $\alpha$ \\
\hline 1 & $.849^{a}$ & .720 & 3.09592 & & 8.776 & 27 & .041 & \\
\hline Teach & & & & .434 & 3.018 & & & 0.76 \\
\hline Human & & & & .253 & 1.600 & & & 0.75 \\
\hline Techno & & & & .129 & .852 & & & 0.79 \\
\hline Evaluate & & & & .045 & .285 & & & 0.87 \\
\hline Culture & & & & .174 & 1.140 & & & 0.87 \\
\hline
\end{tabular}

a. Predictors: (Constant), teaching competence, human competence, technology competence, evaluation competence, and cultural competence.

b. Dependent variable: Classroom practices

Table shows that the whole professional development variables have statistically significant effect on classroom practices in Saudi Universities $(\mathrm{R}=.849 ; \mathrm{p}=.041)$. To further search which of the professional development variables have more impact on classroom practices among the three Saudi Universities. Table 9 shows the results as follows:

Table 9. Model Summary for Teaching Competence

\begin{tabular}{llllllll}
\hline \multirow{2}{*}{ Model } & & & \multicolumn{5}{l}{ Standardized Coefficients } \\
\cline { 5 - 7 } & $\mathrm{R}$ & $\mathrm{R}^{2}$ & Std. Err & Beta & $\mathrm{t}$ & $\mathrm{df}$ & Sig. \\
\hline 1 & $.613^{\mathrm{a}}$ & .376 & 3.09348 & & 15.667 & 1 & .003 \\
Teaching & & & & .439 & 3.201 & & \\
\hline
\end{tabular}

a. Predictors: (Constant), teaching competence.

b. Dependent variable: Classroom practices.

Table 9 shows that teaching competence as a subset of professional development has a statistically significant effect on classroom practices $(\mathrm{R}=.613 ; \mathrm{p}=.003)$. Table 10 shows that technology competence is next to teaching competence in rank.

Table 10. Model Summary for Technology Competence

\begin{tabular}{|c|c|c|c|c|c|c|c|}
\hline \multirow[b]{2}{*}{ Model } & \multirow[b]{2}{*}{$\mathrm{R}$} & \multirow[b]{2}{*}{$\mathrm{R}^{2}$} & \multirow[b]{2}{*}{ Std. Err } & \multicolumn{4}{|c|}{ Standardized Coefficients } \\
\hline & & & & Beta & $\mathrm{t}$ & df & Sig. \\
\hline 1 & $.431^{\mathrm{a}}$ & . 186 & 3.53203 & & 12.489 & 6 & .000 \\
\hline Technology & & & & .179 & 2.001 & & \\
\hline
\end{tabular}

a. Predictors: (Constant), technology competence.

b. Dependent variable: Classroom practices. 
Table 10 shows that technology competence as a subset of professional development is found to have a minimal statistically significant effect on classroom practice $(\mathrm{R}=.431 ; \mathrm{p}=.000)$. Table 11 shows that evaluation competence is next to technology competence.

Table 11. Model Summary for Evaluation Competence

\begin{tabular}{|c|c|c|c|c|c|c|c|}
\hline \multirow[b]{2}{*}{ Model } & \multirow[b]{2}{*}{$\mathrm{R}$} & \multirow[b]{2}{*}{$\mathrm{R}^{2}$} & \multirow[b]{2}{*}{ Std. Err } & \multicolumn{4}{|c|}{ Standardized Coefficients } \\
\hline & & & & Beta & $\mathrm{t}$ & df & Sig. \\
\hline 1 & $.347^{\mathrm{a}}$ & .120 & 3.62469 & & 14.811 & 5 & .000 \\
\hline Evaluation & & & & .087 & -.574 & & \\
\hline
\end{tabular}

a. Predictors: (Constant), evaluation competence.

b. Dependent variable: Classroom practices.

Table 11 shows that evaluation competence as a subset of professional development is found to have a minimal statistically significant effect on classroom practices in the three selected Saudi Universities $(\mathrm{R}=.347 ; \mathrm{p}=.000)$. Table 12 shows the results of human competence.

Table 12. Model Summary for Human Competence

\begin{tabular}{llllllll}
\hline \multirow{2}{*}{ Model } & & & & \multicolumn{3}{l}{ Standardized Coefficients } \\
\cline { 6 - 8 } & $\mathrm{R}$ & $\mathrm{R}^{2}$ & Std. Err & Beta & $\mathrm{t}$ & $\mathrm{df}$ & Sig. \\
\hline 1 & $.276^{\mathrm{a}}$ & .076 & 3.71355 & & 12.125 & 5 & .000 \\
human & & & & .183 & 1.222 & & \\
\hline
\end{tabular}

a. Predictors: (Constant), human competence.

b. Dependent variable: Classroom practices.

Table 12 shows that human competence has a weak statistically significant effect on classroom practices in the Saudi Universities $(\mathrm{R}=.276 ; \mathrm{p}=.000)$. Table 13 shows the results of cultural competence.

Table 13. Model Summary for Cultural Competence

\begin{tabular}{llllllll}
\hline & & & & \multicolumn{3}{l}{ Standardized Coefficients } \\
\cline { 5 - 7 } Model & $\mathrm{R}$ & $\mathrm{R}^{2}$ & Std. Err & Beta & $\mathrm{t}$ & $\mathrm{df}$ & Sig. \\
\hline 1 & $.273^{\mathrm{a}}$ & .075 & 3.71706 & & 13.041 & 5 & .000 \\
Cultural & & & & .265 & 1.803 & & \\
\hline
\end{tabular}

a. Predictors: (Constant), cultural competence.

b. Dependent variable: Classroom practices.

Table 13 shows that cultural competence has the weakest statistically significant effect on classroom practices in Saudi Universities $(\mathrm{R}=.273 ; \mathrm{p}=.000)$.

The results of this study are in consistent with the studies of Berman and Ritchie (2006) and Bhargava \& Pathy (2011) that found the relationship between teaching competence and classroom practice, Schnonert-Reichl and Lawlor (2010) which found the relationship between human competence and classroom practice, Keengwe (2007) which found the relationship between technology competence and classroom practices, Ololube (2008) and DiPerna (2004) who found the relationship between evaluation, cultural competence and classroom practices.

\section{Recommendations}

This study found that, the Saudi Universities have greatly contributed to classroom practices in terms of teaching competences and technology competence, however, they lack in terms of human, evaluation and cultural competences. The study recommends that, the University authorities as well as Saudi Government should focus more on developing the teaching staff in the lacking areas without neglecting the strong areas. This study suggests that, the teaching staff need pre and post professional training because that will help develop their professional competence, 
lead to their teaching practices, and the learning outcomes. The researchers recommend that, the teaching staff need to have certificate of teaching in higher education before embarking on teaching as known globally.

\section{References}

An-Nuh, M. A. (2006). Teaching problems at the teachers' colleges in Saudi Arabia. Arab Gulf Journal for Scientific Research, 98.

As-Shahrani, A. A. (2013). Higher education and different teaching method. Al-Watan Journal. Access Date: 8 January 2013.

Berman, J., \& Ritchie, L. (2006). Competences of undergraduate business students. Journal of Educationfor Business, 81(4), 205-209. http://dx.doi.org/10.3200/JOEB.81.4.205-209

Bhargava, A., \& Pathy, M. (2011). Perception of student teachers about teaching competencies. American International Journal of Contemporary Research, 1(1).

DiPerna, J. C. (2004). Structural and concurrent validity evidence for the academic competence evaluation scales $\begin{array}{lllll}\text { college edition. Journal of College } & \text { Counseling, } & 7(1), & \text { 64-72. }\end{array}$ http://dx.doi.org/10.1002/j.2161-1882.2004.tb00260.x

Guskey, T. R. (1985). Staff development and teacher change. The Association for Supervision and Curriculum Development.

Guskey, T. R. (2002). Professional development and teacher change. Journal of Teachers and Teaching: Theory and Practice. Taylor and Francis.

Hansen, U., Hennig-Thurau, T. \& Wochnowski, H. (2000). Teach,q: Ein valides und Hand habbares Instrument zur Bewertung von Vorlesungen", in Stauss, B., Balderjahn, I.and Wimmer, F. (Eds), Dienstleistungsorientierung in der universita" ren Ausbildung, Scha"ffer-Poeschel, Stuttgart, 311-45.

Keengwe, J. ( 2007). Faculty integration of technology into instruction and students' perceptions of computer technology to improve student learning. Journal of Information Technology Education, 6.

Lebeau, D. (2008). The importance of professional development. Access Date: 13 December 2014.

Mehdipour, Y. \& Balaramulu, D. (2013). Students' attitude toward teacher's behavior in hyderabad universities. International Journal of Scientific and Research Publications, 3.

National Staff Development Council, (2009). Definition of professional development. National Staff Development Council for Inclusion in the Reauthorization of the Elementary and Secondary Education Act.

Ololube, N. P. (2008). Evaluation competencies of professional and non-professional teachers in Nigeria. Elsevier, Journal of Science Direct, Studies in Educational Evaluation. http://dx.doi.org/10.1016/j.stueduc.2008.01.004

Ratcliff, N. J. Jones, C. R., Costner, R. H., Savage-Davis, E., \& Hunt, G. H. (2010). The elephant in the classroom: The impact of misbehavior on classroom climate. Eric Publication.

Schnonert-Reichl , K. A., \& Lawlor, M. S. (2010). The effects of a mindfulness-based education program on pre-and early adolescents' well-being and social and emotional competence. Springer Science and Business Media Publication.

Wong, W. Y., \& Moni, K. (2014). Teacher's perceptions of and responses to student evaluation of teaching: purposes and uses in clinical education. Journal of Assessment and Evaluation in Higher Education. http://dx.doi.org/10.1080/02602938.2013.844222 